\title{
On the Nexus Between CSR Practices, ESG Performance, and Asymmetric information
}

\author{
Berto Usman *a Oscar Tiago Fontes Bernardes, Paulus Sulluk Kananlua \\ ${ }^{a}$ University of Bengkulu, Indonesia \\ ${ }^{\mathrm{b} P}$ Porto Accounting and Business School, Portugal
}

\begin{abstract}
The purpose of this paper is to test the relationship of CSR practices-asymmetric information and ESG performance-asymmetric information. We conjecture that there might be a particular role where the disclosure of non-financial information is deemed useful in truncating the level of asymmetric information. Using data from two different countries, Indonesia (Asia) and Portugal (Europe), we extracted 37 companies; the time period of the observation was from 2012 to 2016. To manifest the empirical test, we used CSR report (CSR_Rep), CSR committee (CSR_com), CSR assurance (CSR_ass) and GRI adoption as the proxies of CSR practices, while the proxies of ESG performance were represented by environmental (ENVscr), social (SOCscr), and governance (GOVscr) pillar scores, as obtained from Thomson Reuters ASSET4 database. The bid-ask spread was used as the surrogate indicator of asymmetric information. The empirical test revealed that only the variables GRI and SOCscr showed a negative and significant association with the bid-ask spread; whilst the remaining variables of CSR practices (CSR_rep, CSR_com, CSR_ass), and ESG performance (ENVscr and GOVscr) were negatively associated with asymmetric information (Spread) but are statistically insignificant. Our results suggested that CSR practices and ESG performance are contemporaneous and weakly associated with asymmetric information, while this association gets stronger when we run the model using lagged independent variables. We thus infer that the information on CSR reporting practices and ESG performance scores need some time lag to be fully absorbed by the market participants and to be reflected in the bid-ask price changes.
\end{abstract}

Keywords: CSR practices, ESG performance, asymmetric information

JEL Classification: M0, M4, M41 


\section{Introduction}

The number of studies into corporate social responsibility (CSR) is increasing profoundly (Patten and Zhao, 2014; KPMG, 2015; E and Y, 2017; KPMG, 2017). This is triggered by the increasing awareness of the importance of sustainability practices. As reported by Klynveld Peat Marwick Goerderler or KPMG International Cooperative 2017, in a survey of corporate responsibility reporting, the number of CSR reports had doubled. KPMG documented that from 1993 to 2017, the increase in global CSR reporting was 93 percent higher for the G250 big companies (the world's 250 largest companies by revenue based on Fortune 500 ranking of 2016). This result shows that more and more companies are now recognizing CSR reporting as one of the important channels to communicate companies' CSR-related engagements to the public. This information is possibly required in order to diminish the potential asymmetric information that may exist among stakeholders (Leuz and Verrecchia, 2000). However, stakeholders may have few ideas and little information to better understand the essence behind the reported information (Bagnoli and Watts, 2017). Thus, environmental, social, and governance rankings, as the indicators of CSR performance, are deemed useful to measure the effectiveness of companies' non-financial impacts. Given the interesting issues and the growing phenomenon of global CSR reporting, we therefore designed this study to identify the association between CSR practices, ESG (environmental, social, and governance) performance, and asymmetric information.

In this study, we try to shed light on the unexplored link between CSR practices, ESG performance, and asymmetric information in two different stock markets - the Indonesian and Portuguese stock exchanges. We considered these two stock markets to be interesting settings given the CSR-related regulations that have been enacted in these two countries. In most of the developed countries in Europe, non-financial disclosure is regulated through Directive 2014/95/EU of the European Parliament (European Commission, 2014), which requires all publicly listed companies in Europe to mandatorily disclose their non-financial and diversity information to the public. Meanwhile, in the setting of developing countries such as Indonesia, mandatory non-financial information's disclosure through CSR reporting has been enacted through a national policy under the article 15 of the 2007 investment Law No 25 (Waagstein, 2011). However, article 74 of the 2007 Limited Liability Corporation Law No 40 indicates that CSR practices are required for companies operating in the sector that has a direct relationship with natural resources exploration (Hendarto, 2009; Waagstein, 2011; Famiola and Adiwoso, 2016). Given the institutional setting's background of CSR reporting in these two countries, we also envisage that the implementation of CSR practices and the association of ESG performance with asymmetric information might behave differently between the developed and developing economies. The study by Muller and Kolk, (2009) presented a survey of CSR performance (i.e., measured by environmental, labor, and community dimensions) among the Mexican auto industry. They found that companies in the emerging-market context have tried to resemble the so-called "western standards" of CSR practices from the developed countries. As a result of this, the local companies indicate some improvements in their ways of dealing with more comparable reporting to what is known about CSR in a developed country setting. Yet, this im- 
provement is insufficient and just beyond the optimum expectation of common CSR practices in the developed countries. Furthermore, in the literature study of Brooks and Oikonomou, (2018) the relationship between CSR performance and financial performance generally showed an uncertain shape, whether it generates linear or non-linear relationship, and forms a particular type of non-linearity. Therefore, to deal with this puzzle, we deliberately proposed two main research questions. First, we question whether CSR practices are associated with asymmetric information? Second, we wonder if the ESG performance is associated with asymmetric information?

To deal with the proposed research questions, we built upon several previous works of literature in addressing our research questions. Our first research question was whether CSR practices are associated with asymmetric information. In regards to the utilization of CSR practices as the main concept, we adopted CSR practices based on the study conducted by Michelon, Pilonato, and Ricceri, (2015). In their study, they particularly employed the presence of CSR reports, CSR assurance, and Global Reporting Initiative (GRI) adoption as the components of any CSR practice, and further tested their association with CSR's disclosure quality. However, our study is different from the study of Michelon, et al., (2015) in terms of the dependent variable, as we proposed asymmetric information as our dependent variable. To further advance this study, we considered inserting the information regarding CSR committees as one of the proxies of CSR practices. We assumed that the presence of a CSR committee is relevant as it has a particular role in helping the company shape its management decisions regarding the CSR-related policies. Moreover, to empirically mani- fest the concept of asymmetric information, we followed the studies of Cho, Lee, and Pfeiffer, (2013), Fuhrmann, Ott, Looks, and Guenther, (2017), and Usman and Yennita, (2018) by utilizing the information with respect to the bid-ask spread value. We used the spread as the proxy of asymmetric information due to its ability to reflect the current condition of information absorbed by the market (Ding and Hou, 2015).

Our second research question aimed to identify whether ESG performance relates to asymmetric information. This research question was developed by referring to the previous studies testing the association between CSR (ESG) performance and asymmetric information. Among them, the study of Cho, Lee, and Pfeiffer, (2013) provided an empirical base of study where they documented that there is a negative association between CSR performance (ESG performance) and asymmetric information (bid-ask spread). Their findings reported that the negative association between CSR performance and bid-ask spread was lower for companies with a higher concentration of institutional investors, whilst those companies with a lower level of institutional investors underwent a relatively higher negative association. In this respect, the study of Nurazi, Usman, and Kananlua, (2016) pointed out that the availability of environmental and social disclosures may drive the investment decisions taken by the buyers and sellers. However, in the order-driven market and the equity market system, buyers and sellers cannot directly initiate their transaction activity since they need a broker to execute each transaction (Nurazi et al., 2016). Therefore, the up and down of the bid-ask spread is somehow also determined by the supply and demand of the equity and the brokers' participation in the market. 
Overall, our empirical findings showed that contemporaneous $\left(\mathrm{t}_{0}\right)$ CSR practices and ESG performance are negatively associated with asymmetric information in the current year $\left(t_{0}\right)$. Utilizing several proxies for CSR practices (i.e., CSR report, CSR committee, CSR assurance, and GRI) and ESG performance (i.e., environmental, social, and governance pillar scores), we tested their association with asymmetric information, which was proxied by the bid-ask spread. The obtained empirical outputs, using a stand-alone sample of each particular country, showed that CSR practices and ESG performance are negatively associated with asymmetric information (bidask spread). In particular, we found that only GRI is statistically associated with the bid-ask spread. Meanwhile, the remaining hypotheses indicated a negative association, which was statistically insignificant. Given this empirical finding, we further tested the robustness of our findings by employing one-year timelagged independent variables. The obtained output using the pooled sample with lagged variables was slightly different from the main analysis of the pooled sample with contemporaneous independent variables of interest. However, the result of the robustness check remained consistent with the a priori notion in our hypotheses development.

The contribution of this study is threefold. First, this study is the first research to deliberately highlight the differences of two institutional settings for the background of the study. We utilized two different countries in Asia and Europe: Indonesia and Portugal, where CSR reporting has become a mandatory practice. Second, the findings of this study are relevant to stakeholders, so they can better comprehend the relevance of CSR practices and ESG performance in explaining the variation of asymmetric information. Third, the extensive literature has provided the test for the relationship between CSR practices-asymmetric information, and ESG (CSR) performance-asymmetric information. However, no prior study provides the empirical test by presenting these three concepts at the same time in the same proposed research model. Thus, we are aiming at enriching the literature by providing empirical evidence on the nexus between CSR practices-asymmetric information, and ESG (CSR) performance-asymmetric information.

The remainder of this paper is structured as follows. The section for the literature review and hypotheses development provides the theoretical base of the proposed hypotheses. The research method section elaborates on the sample's selection, the operational definition of the variables, the data's collection, and the predictive regression model. The findings of the study are provided and discussed in the results and discussion section. The last section has the concluding remarks together with the implication and the study's limitation.

\section{Literature Review and $\mathrm{Hy}-$ potheses Development}

\section{CSR Practices and Asymmetric infor- mation}

We use legitimacy theory and the signaling theory as the underlying reason behind our hypotheses development. As previously stated by Suchman, (1995 p. 574) legitimacy theory is defined as "a generalized perception or assumption that the action of an entity is desirable, proper, or appropriate within some socially constructed system of norms, values, beliefs, and definitions." Meanwhile, the signaling theory, as stated by Stiglitz, (2002 p. 
473) indicates that "some individuals wish to convey information and others wish not to have information conveyed, but in either case, the fact that actions to convey particular items of information lead people to alter their behavior," and this is why information imperfections have such a profound effect. As reported by Connelly, Certo, Ireland, and Reutzel, (2011) the signaling theory and asymmetric information have a close relationship and provide a unique, practical, and testable perspective in the setting of a social science study. In particular, the effort to obtain legitimacy and signaling the information to the public is conducted by companies in their corporate reporting activities (i.e., financial or non-financial related information disclosures). One of the types of reporting procedure that we highlighted in this study is the disclosure of non-financial information through CSR practices, and its implication on the asymmetric information environment. Thus, we adopt legitimacy and the signaling theory as the base arguments to explain the potential relationship between CSR practices and asymmetric information.

Regardless of the potential motives for gaining legitimacy and delivering a signal to the general public, companies may have several options for dealing with their non-financial information disclosures to the public. First, as highlighted by Deegan, Cooper, and Shelly, (2006) and Mahoney, Thorne, Cecil, and LaGore, (2013), companies might choose to publish their CSR information through a stand-alone report that could be known by several names (e.g., a CSR report, CR report, sustainability report, environmental report, ESG report, triple bottom line report, and so forth). These reports solely account for environmental, social, and governance information. Second, companies might employ integrated reporting, in which CSR-re- lated information is provided in their annual reports (an integrated annual report, registrant report, or consolidated annual report). In these forms, CSR-related information is provided in a dedicated section of the report (Habek and Wolniak, 2016). Given the nature of the different CSR reporting practices that are conducted, based on their comprehensive cost-and benefit analysis, companies need to make sure that engaging in CSR reporting would result in a positive effect on the companies' performance (Cormier and Magnan, 2015).

When the companies have their CSR reports published and disseminated to the public, it is expected that the firms' performances will be positively corrected (Lys, Naughton, and Wang, 2015). Thus, one of the indicators of a firm's performance can be seen from its stock liquidity. High liquid stock reflects that investors are more likely to pay attention to the active stock, which shows the presence of low asymmetric information among the market participants (Usman and Tandelilin, 2014; Nurazi, Usman, and Kananlua, 2016; Nurazi and Usman, 2019). Several studies have examined the relationship between CSR information and asymmetric information. Among them, Lang and Lundholm, (2000) tested corporate disclosure activity near an equity offering and its association with stock prices. They discovered that in the six months before the offering is conducted, the firms were more likely to dramatically increase their disclosure activity, which indicated an effort to lower the level of asymmetric information. Moreover, in a more detailed empirical test, the study by Cho et al., (2013) presented the finding that CSR reporting is associated with asymmetric information. Their result showed that there is a negative association between CSR reports and the bid-ask spread. This negative association decreases for companies 
that are dominated by a high level of institutional investors, relative to companies with a lower level of institutional investors. Given the relationship between CSR practices and asymmetric information, we expect that the more companies engage in CSR practices (CSR reporting), the lower the asymmetric information will be.

\section{H1a: CSR reporting is negatively associated with asymmetric information.}

In Hypothesis 1b, we conjecture that the corporate governance mechanism may facilitate companies to better observe their management and control activities (La Porta, Lopez-de-Silanes, Shleifer, and Vishny, 2000; Nurazi, Santi, and Usman, 2015). Since the attention and focus on sustainable development is growing profoundly, companies might need to manage their CSR-related decisions professionally, by forming a CSR committee (Peters and Romi, 2015). This is essential since corporate governance and non-financial information disclosure decisions are a complementary mechanism for legitimacy practices, that could be used by the companies to convey their message to the stakeholders and general public (Michelon and Parbonetti, 2012). For this reason, we expect that CSR committees may help the companies to deal with their CSR-related activities in better ways, as the companies with CSR committees are supposed to have better monitoring mechanisms and policy implementation for their CSR action plans. Given that, we consider that asymmetric information which is reflected through the bid-ask spread changes can be mitigated to a lower level. In addition to this, the knowledge and information of firms' disclosure activities are publicly available and can be utilized by the investors or related stakeholders to manage their investment decisions (Cho et al., 2013).
This can also be observed from the perspective of the stakeholders' points of view, where the presence of a CSR committee is expected to play a positive role in increasing stock liquidity and leads to a lower spread in the bid-ask price. In this regard, the actions taken by the CSR committee through its CSR policy in the corporate disclosure represent public interests, and may influence investors' purchase decisions (Amran, Lee, and Devi, 2014). When the CSR committee makes a decision and conveys this information to the public, we expect that companies are more likely to have a higher trading volume, which tends to lead to a tighter spread than for those companies with a low trading volume. Thus, we developed Hypothesis $1 \mathrm{~b}$ as follows:

\section{H1b: A CSR committee is negatively associated with asymmetric information.}

Given the voluntary nature of CSR practices and their reporting, there is a chance that companies may deal with the misappropriation of the CSR report. Take, for instance, the motives of impression management actions (Rutherford, 2003), hypocrisy (Michelon, Pilonato, Ricceri, and Roberts, 2016), using the CSR report as a camouflaging tool (Moneva, Archel, and Correa, 2006), reputation risk management (Bebbington, Larrinaga, and Moneva, 2008), and solely ticking the box for CSR dimensions might harm the main objective of the CSR's function as the source of value-relevance information (Junior and Best, 2017; Usman, 2020b). Due to the presence of these opportunistic behaviors, it may potentially increase the asymmetric information between the report preparer (companies) and the report users (the general public). The report preparer might obfuscate the reported information so as to make the negative tone (i.e., negative news) less recognizable by using more difficult words. As a result of this, 
the content and the essence of the report cannot be fully appreciated by the stakeholders, as the report's users. In this respect, Bagnoli and Watts, (2017) affirmed that it is the company that knows very well the actual level of its CSR engagement, as the company has the opportunity to manage and select the type of information it prefers to disclose voluntarily. Meanwhile, the stakeholders can only observe this information through the final CSR report published by the company. To reduce this asymmetrical information condition, companies are expected to fairly and truthfully disclose their non-financial information to the public. However, even though companies have reported their non-financial dealings through many different reports and channels, there could still be the veiled opportunity that companies misuse their CSR reports to manage their stakeholders' perceptions (Neu, Warsame, and Pedwell, 1998; Bebbington et al., 2008; Birkey, Michelon, Patten, and Sankara, 2016; E and Y, 2017). Given that, the credibility and reliability of CSR reports are highly uncertain, doubted, and often questioned by the stakeholders (Hodge, Subramaniam, and Stewart, 2009; Briem and Wald, 2018). In order to anticipate criticism of the credibility and reliability of the information disclosed in the CSR report, companies are recommended to have their reports vetted by a third, independent, party (Mercer, 2004; Moroney et al., 2011; Cho, Michelon, Patten, and Roberts, 2014; Romero, Fernandez-Feijoo, and Ruiz, 2014).

Engaging with the vetting practice may indicate a positive signal of companies' readiness to being scrutinized by a third-party (i.e., assurance provider ${ }^{1}$ ) (Manurung and

${ }^{1}$ The vetting service providers of CSR information can be professional accountants (i.e., BigN vs. NonBigN) and non-accountants (e.g., consultancy firms; environmental consultants, environmental and engineering consultants, environmental research organizations, and so forth) (Deegan et al., 2006; Manurung and Basuki, 2010; Moroney et al., 2011; Simnett, Vanstraelen, and Chua, 2009).
Basuki, 2010; Moroney et al., 2011; Lys et al., 2015). The study by Fuhrmann, Ott, Looks, and Guenther, (2017) revealed that using a matched sample (CSR reports with vs. without assurance) from 442 STOXX 600 European companies, checking the contents of the CSR reports using a high-quality vetting process was negatively associated with asymmetric information proxied by the bid-ask spread. Meanwhile, they also showed that CSR reports with a moderate vetting level are deemed insufficient, as a vetting process that ensures only a moderate level of certainty is not significantly associated with the decrease of information asymmetry. Thus, we conjecture that having the CSR report vetted and certified might help the stakeholders to truncate the level of asymmetric information between the company, as the report's preparer, and the stakeholders as the report's users. Taking into consideration the above discussion, we proposed Hypothesis 1c as follows:

H1c: CSR vetting is negatively associated with asymmetric information.

Prior studies have documented that there is no particular or specific format that should be adopted by companies when dealing with CSR reporting. However, more and more non-profit organizations are developing and providing frameworks that focus on helping the companies disclose the particular non-financial information metrics of their CSR dimensions (Pérez, 2015; Pope and Wrraas, 2016; Khan, Serafeim, and Yoon, 2016). Take, for instance, the Global Reporting Initiative (GRI), which is one of the most adopted disclosure frameworks (Brown, de Jong, and Levy, 2009; GRI, 2014; Hahn and Lulfs, 2014). GRI has been developed, modified, and evolved over time, based on the information needs of stakeholders. A number of the non-financial metric parameters 
in GRI are deemed to be alternative tools to better quantify non-financial information, so as to make it more measurable and comparable. If a company does not adopt any framework for its CSR reporting, there is a probability that the published information does not comprehensively cover the material information, and is most likely to be seen as a less standardized and less comparable report (Deegan et al., 2006; Khan et al., 2016). Therefore, GRI's adoption to some extent expresses a signal that companies have a higher commitment to more organized CSR reporting. In this context, the GRI's disclosure framework also covers broader aspects, which capture and reflect the non-financial indicators of the environmental, social, and governance impacts of firms' activities (GRI, 2014). As a result of this, stakeholders (investors) may utilize the information in a CSR report as a source of value-relevance information to mitigate the asymmetric information. Hypothesis 1d is organized as follows:

H1d: The Global Reporting Initiative (GRI) is negatively associated with asymmetric information.

\section{ESG Performance and Asym- metric information}

An ESG performance score is created based on the evaluation of the available CSR reports made to the public. CSR ranking institutions (e.g., Thomson Reuters ASSET4, Bloomberg, KLD, Sustainalytics, Reputation Institute, and so forth) use the voluntary disclosure documents released by the companies to assess their environmental, social, and governance impacts. In this regard, the companies' sincerity and their commitment to ESG aspects can be seen from their ESG-related expenditure, and how this activity is reported to the public (Steinmeier and Stich, 2017; Yoon, Lee, and Ryan, 2018). Pri- or studies have well-documented that ESG performance scores help the stakeholders to better understand the degree of impact the companies have with respect to their ESG activities (Benlemlih, Shaukat, Qiu, and Trojanowski, 2016). Take, for example, Dhaliwal, Radhakrishnan, Tsang, and Yang, (2012) who reported that CSR information can be used by professional stakeholders (i.e., financial analysts, institutional investors, securities companies, etc.) to reduce the condition of asymmetric information as indicated by the analysts' earnings forecast accuracy through the analysts' forecast error and analysts' earnings dispersion for three different forecast horizons $\left(t_{0}, t_{+1}\right.$, and $\left.t_{+2}\right)$. When Benlemlih et al., (2016) extended the study of Dhaliwal et al., (2012) using environmental and social disclosure performance scores, they found a negative relationship between these disclosure scores and companies' total risk and idiosyncratic risk. They pointed out that the presence of non-financial information is value relevant in reducing the potential risks for the stakeholders. Moreover, CSR information is also considered useful for green investors ${ }^{2}$, who pay more attention not only to a business's sustainability but also to its resource's and environmental sustainability. Given that, the professional and non-professional stakeholders may simply capture the relevance of ESG performance scores to mitigate the level of asymmetric information. In this regard, ESG performance scores could be interpreted as the signal that a better score is more likely to indicate lower asymmetric information, as the companies become more responsible, accountable, and transparent in their ESG activities. Therefore, we hypothesized that the environmental, social, and gov-

${ }^{2}$ Investors who hold securities listed in the so-called "green equity indexes" e.g., SandP 500 Environmental and Socially Responsible Index, Nasdaq Clean Edge Green Energy Index (CELS), FTSE Green Revenues Index Series, Dow Jones Sustainability Index, and so forth. 
ernance performance scores are negatively associated with asymmetric information.

H2a: The environmental score is negatively associated with asymmetric information.

H2b: The social score is negatively associated with asymmetric information.

H2c: The governance score is negatively associated with asymmetric information.

\section{Research Design}

To better manifest the proposed conceptual idea and its technical measures, we designed our study as a research model. The following boxes in Figure 1 show the proposed relationship links between the main concepts, as well as the operationalization of the conceptual ideas into several surrogate indicators.

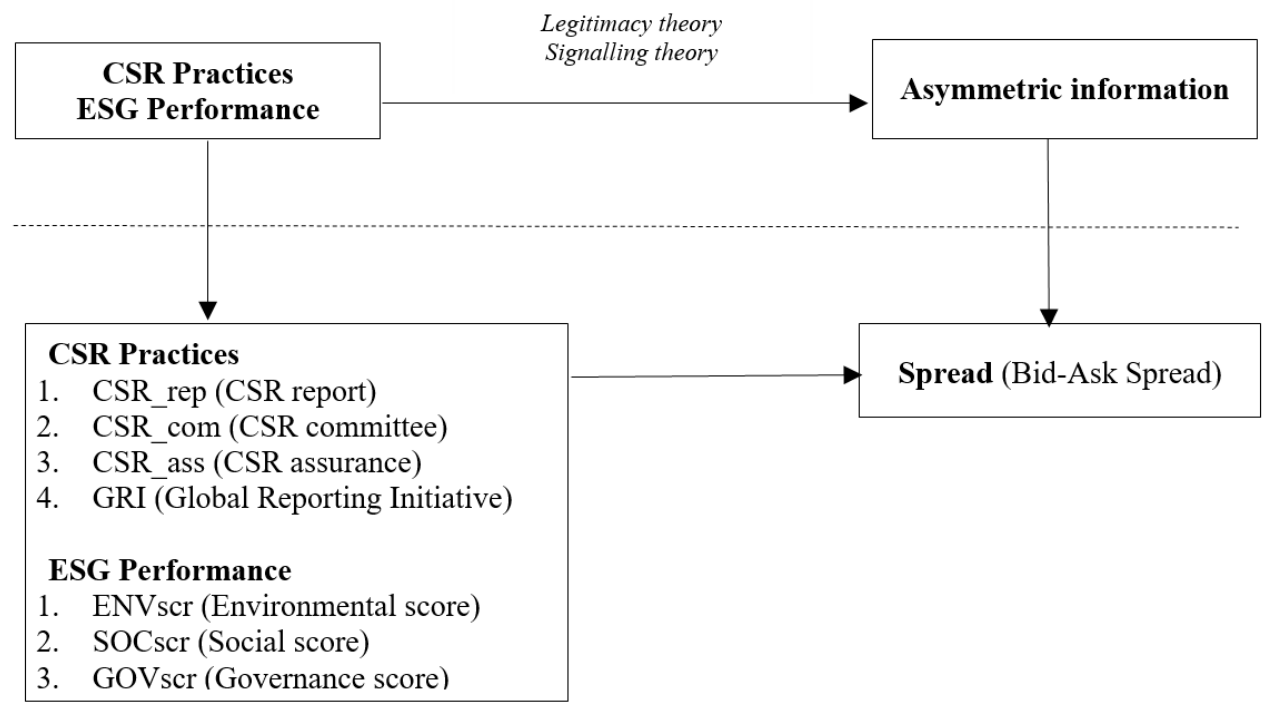

Figure 1. Research model

Figure 1 displays the research model for our study. In the model, we distinguish between the proposed conceptual idea, and further manifest the idea into measurable parameters. As seen in the boxes, the main idea is proposing the empirical test for the relationship between CSR practices, ESG performance, and asymmetric information. CSR practices are further operationalized by employing several variables such as: the availability of CSR reports, the presence of CSR committees, the vetting of CSR reports, and the adoption of the GRI framework. ESG performance is proxied by the environmental, social, and governance performance scores. To technically operationalize the asymmetric information, we used the bid-ask spread value.

\section{Methods}

\section{Sample and Data Collection}

The sample of our study is taken from two countries (Portugal and Indonesia). We particularly chose these two countries be- 
non-financial disclosure and its reporting have been enacted in Indonesia since 2007, specifically through the national policy under the article 15 of the 2007 investment Law No 25 , which obliged every corporation to implement CSR activity (Waagstein, 2011). However, even though the mandatory reporting of non-financial information has been enacted, the procedure for non-financial disclosure and its reporting are still unstructured. Thus, we have adopted purposive sampling techniques with several criteria for screening the potential sample. The first of these criteria is that the sample (company) should be publicly listed on the Indonesian Stock Exchange and/ or the Portuguese Stock Exchange. Second, we focus on a number of companies that were consistently listed during the time period of our observation (from 2012 to 2016). Third, the company should have published at least one CSR report during the period of observation. Fourth, the company should be covered by the CSR ranking institution (the ASSET4) to enable us to collect complete data on the ESG performance scores. Last, the company should have had complete financial data. environmental, social, and governance performance pillar scores) were extracted from the ASSET4 database, and financial-related information was extracted from the EIKON datastream. Moreover, the data on our main dependent variable (asymmetric information) is proxied by calculating the bid-ask spread value. We are aware that our main independent variables (i.e., CSR practices and ESG performance) cannot fully explain the variation of asymmetric information. As pointed out by Lennox, Francis, and Wang, (2012), most of the implications of the accounting and finance policies are considered as choicebased decisions, because of many endogenous factors. Thus, we acknowledge that our model could potentially be harmed by an endogeneity problem (i.e., omitted correlated variable bias). To handle this issue, we further decided to insert several firm-specific variables as additional control variables. These control variables were adopted from the previous studies which are commonly used by researchers in the CSR arena. The sampling procedure of our study is available as follows.

Table 1. Sample selection procedure

\begin{tabular}{|c|c|c|c|c|c|c|c|}
\hline \multirow[t]{2}{*}{ No } & \multirow[t]{2}{*}{ Sample construction procedure } & \multicolumn{2}{|c|}{ Indonesia } & \multicolumn{2}{|c|}{ Portugal } & \multicolumn{2}{|c|}{ Pooled sample } \\
\hline & & (n) & (obs) & (n) & (obs) & (n) & (obs) \\
\hline 1 & $\begin{array}{l}\text { Total companies listed on the capital markets } \\
\text { (current data in the last semester of 2018). }\end{array}$ & 592 & 2,960 & 68 & 340 & 660 & 3,300 \\
\hline 2 & $\begin{array}{l}\text { Companies with no CSR report as covered by } \\
\text { ASSET4 database from } 2012 \text { to } 2016 \text {. }\end{array}$ & $(564)$ & $(2,820)$ & $(59)$ & $(295)$ & $(623)$ & $(3,115)$ \\
\hline 3 & $\begin{array}{l}\text { Companies with complete yearly-observations } \\
\text { and fundamental financial data from } 2012 \text { to } \\
2016 .\end{array}$ & 28 & 140 & 9 & 45 & 37 & 185 \\
\hline Note: & $\begin{array}{l}(\mathrm{n})=\text { Number of companies } \\
(\mathrm{obs})=\text { Company-yearly observations }\end{array}$ & & & & & & \\
\hline
\end{tabular}

Regarding the data's collection, we mainly extracted our financial and non-financial information from Thomson Reuters. The data on CSR practices and ESG-related variables (e.g., sustainability ranking with respect to

\section{Regression Model}

Our study used panel data analysis which combined the cross-sectional and time-series data analyses. More specifically, we use the data from 37 companies or 185 
company year-observations (28 Indonesian; 140 company-year observations, and 9 Portuguese; (45 company-year observations)) which are observed from a different point in time. In this regard, the time-series data were taken for a five years series, spanning from 2012 to 2016. According to the opinion of Pedhazur, (1997) and Baltagi, (2008), the within-subject information (cross-sectional data with 37 public listed companies) and across time (2012-2016) are combined in the process of panel data analysis estimations. The result from the ordinary least squares (OLS) regression model shows the error variance for different cross-section units which corresponds to the presence of heteroskedasticity. Thus, the standard error, as obtained from this OLS estimation, is considered inconsistent. To tackle this issue, we employed a panel corrected standard error model which assumes that the standard errors within the unit (cross-sectional) are homoscedastic (Usman, 2019). Finally, we ran the following statistical model by employing robust variance estimates, and robust standard errors clustered at the year and firm levels.

Spread $_{i, \mathrm{t}}=\alpha+\beta 1 \mathrm{CSR} \cdot \mathrm{rep}_{\mathrm{i}, \mathrm{t}}+\beta 2 \mathrm{CSR} \cdot \mathrm{com}_{\mathrm{i}, \mathrm{t}}+$ $\beta 3 \mathrm{CSR} \cdot \mathrm{ass}_{\mathrm{i}, \mathrm{t}}+\beta 4 \mathrm{GRI}_{\mathrm{i}, \mathrm{t}}+\beta 5 \mathrm{ENVscr}_{\mathrm{i}, \mathrm{t}}+\beta 6 \mathrm{SOCscr}_{\mathrm{i}, \mathrm{t}}+$ $\beta 7 \mathrm{GOVscr}_{\mathrm{i}, \mathrm{t}}+\sum$ Controls $_{\mathrm{i}, \mathrm{t}} \sum$ Year $_{\mathrm{i}, \mathrm{t}}+\sum$ Industry $_{\mathrm{i}, \mathrm{t}}+\varepsilon$.

\section{Dependent Variable}

The dependent variable in this study is asymmetric information. To empirically test this concept, we used the bid-ask spread value $\left(\right.$ Spread $\left._{\mathrm{i},}\right)$ as the proxy of asymmetric information. We used this variable since the difference in the bid and ask price may represent the different types of information owned by the companies as insiders, and stakeholders as the outsiders in the market. With respect to its data form, we use the annual spread data as indicated by firm ${ }_{i}$ in year ${ }_{t}$.

\section{Independent Variables}

The subscript ${ }_{i}$ means firm $i$ and the subscript means the annual time (year $\mathrm{t}$ ). To explain the variation of the dependent variable $\left(\right.$ Spread $\left._{i, t}\right)$, we used seven main independent variables (CSR_rep, CSR_com, CSR_ass, GRI, ENVscr, SOCscr, and GOVscr). These variables represent the idea of CSR practices and ESG performance. In particular, the concept of CSR practices is empirically tested by employing four variables, namely CSR_rep, CSR_com, CSR_ass, and GRI. The ESG performance is surrogate by three performance scores namely ENVscr, SOCscr, and GOVscr. In detail, CSR_rep means the availability of CSR information. We mark companies either with a stand-alone report, or CSR information provided in a dedicated section in the annual report as 1 , and 0 otherwise. CSR_com denotes the availability of a CSR committee. We mark 1 if the companies have CSR committees and 0 otherwise. CSR_ass stands for external vetting of the CSR documents. Companies with certified CSR reports are marked 1 and 0 otherwise. GRI denotes the Global Reporting Initiative. GRI is a disclosure framework used by companies when they are dealing with their CSR disclosures. In this regard, we also used a binary variable, in which the companies who adopted the GRI framework are marked 1, and 0 otherwise. ENVscr is the environmental pillar score, as published by the ASSET4 database for the related sample. This variable is generated in a continuous form from 0 as the lowest score and 100 as the highest score. Moreover, SOCscr and GOVscr denote the social and governance pillar scores as published by the ASSET4 database. The data of SOCscr and GOVscr are provided in a continuous form, as well as the data of ENVscr. 
Gadjah Mada International Journal of Business - May-August, Vol. 22, No. 2, 2020

\section{Control Variables}

We were aware that the OLS regression we used in the proposed model could be harmed by the problem of endogeneity, particularly the issue of omitted correlated variable bias. Therefore, to neutralize the main effect of the independent variables on the variation of the dependent variable, and the potential effect of the non-existence variables in the proposed model, we decided to use control variables. Following the previous studies, we used several financial information items as our control variables. These financial-related variables are: SIZE which governance mechanism. We labeled this variable "Boardsize," which is calculated as the total number of board members.

Apart from the utilization of control variables, we also tested the year fixed-effect and industry fixed-effect. Besides, we used an additional variable named ESIs (environmentally sensitive industries) to distinguish if the companies were operating in environmentally sensitive industries, relative to other industries. The complete information with respect to the variable definition is available as follows.

Table 2. Variable definitions

\begin{tabular}{|c|c|c|c|}
\hline Variable & Definition & Data form & Source \\
\hline Spread & Bid-Ask spread: ask price - bid price / ((ask price + bid price $) / 2)$. & Continuous & EIKON \\
\hline CSR_rep & $\begin{array}{l}\text { CSR report: } 1 \text { if the companies publish a stand-alone or CSR information } \\
\text { in a dedicated section in the annual report, } 0 \text { otherwise. }\end{array}$ & Binary & ASSET4 \\
\hline CSR_com & CSR committee: 1 if the companies have CSR committee and 0 otherwise. & Binary & ASSET4 \\
\hline CSR_ass & $\begin{array}{l}\text { CSR assurance: } 1 \text { if the CSR report is vetted by an external independent } \\
\text { third-party. }\end{array}$ & Binary & ASSET4 \\
\hline GRI & $\begin{array}{l}\text { Global Reporting Initiatives: } 1 \text { if the companies adopt the GRI framework, } \\
0 \text { otherwise. }\end{array}$ & Binary & ASSET4 \\
\hline ENVscr & $\begin{array}{l}\text { Environmental score: environmental pillar score as provided by ASSET } 4 \\
\text { database. }\end{array}$ & Continuous & ASSET4 \\
\hline SOCscr & Social score: social pillar score as provided by ASSET4 database. & Continuous & ASSET4 \\
\hline GOVscr & $\begin{array}{l}\text { Governance score: governance pillar score as provided by the ASSET } 4 \\
\text { database. }\end{array}$ & Continuous & ASSET4 \\
\hline SIZE & Company size: natural logarithm (NL) of total assets. & Continuous & EIKON \\
\hline LEV & Leverage: total debt / total equity. & Continuous & EIKON \\
\hline ROA & Return on Asset: total return / total asset. & Continuous & EIKON \\
\hline Boardsize & The total number of board members. & Continuous & EIKON \\
\hline ESIs & $\begin{array}{l}\text { Environmentally Sensitive Industries: } 1 \text { if the companies operating in envi- } \\
\text { ronmentally sensitive industries (electric, gas, oil, paper \& forest products, } \\
\text { pharmaceuticals), } 0 \text { otherwise. }\end{array}$ & Binary & ASSET4 \\
\hline
\end{tabular}

Notes: Table 2 provides the plot for variable definition, data form, and the source of dataset. The employed variables are adopted from various sources of literature and we further combine them in our empirical test.

is calculated based on the natural logarithm (NL) value of the total asset. LEV denotes the leverage ratio, calculated by dividing the total debt to total equity, and ROA stands for the return on assets. Meanwhile, in order to strengthen the empirical estimation, we also utilized a variable that represents the good

\section{Results}

\section{Descriptive Statistics}

In this section, we provide our elaboration of the obtained data from Indonesia and Portugal. Besides presenting the subset data 
from Indonesia and Portugal separately, we also pooled all the data in a panel data form. The information with respect to the descriptive statistics analysis is available as follows. Table 3 illustrates. main independent variable is divided into two major ideas, namely CSR practices and ESG performance. With respect to CSR practices, we employ four main variables (i.e., CSR_rep, CSR_com, CSR_ass, and GRI). As can be seen in Table 1, the pooled sample shows

Table 3. Descriptive statistics

\begin{tabular}{|c|c|c|c|c|c|c|c|c|c|}
\hline \multirow[b]{2}{*}{ Variable } & \multicolumn{3}{|c|}{ Mean } & \multirow[b]{2}{*}{ stdv } & \multirow[b]{2}{*}{ p25th } & \multirow[b]{2}{*}{ p50th } & \multirow[b]{2}{*}{ p75th } & \multirow[b]{2}{*}{ Min } & \multirow[b]{2}{*}{$\operatorname{Max}$} \\
\hline & $\begin{array}{c}\text { Pooled } \\
(185 \\
\text { obs }) \\
\end{array}$ & $\begin{array}{c}\text { Indone- } \\
\text { sia (140 } \\
\text { obs) }\end{array}$ & $\begin{array}{l}\text { Portu- } \\
\text { gal (45 } \\
\text { obs) }\end{array}$ & & & & & & \\
\hline \multicolumn{10}{|c|}{ Panel A. Dependent variable } \\
\hline Spread & 0.008 & 0.006 & 0.016 & 0.031 & 0.003 & 0.004 & 0.007 & 0.000 & 0.405 \\
\hline \multicolumn{10}{|c|}{ Panel B. Independent variables } \\
\hline CSR_rep & 0.665 & 0.621 & 0.800 & 0.473 & 0 & 1 & 1 & 0 & 1 \\
\hline CSR_com & 0.395 & 0.271 & 0.778 & 0.490 & 0 & 0 & 1 & 0 & 1 \\
\hline CSR_ass & 0.232 & 0.143 & 0.511 & 0.424 & 0 & 0 & 0 & 0 & 1 \\
\hline GRI & 0.400 & 0.364 & 0.511 & 0.491 & 0 & 0 & 1 & 0 & 1 \\
\hline ENVscr & 47.344 & 40.600 & 68.323 & 22.867 & 26.549 & 48.529 & 69.196 & 8.114 & 92.445 \\
\hline SOCscr & 57.100 & 54.072 & 66.519 & 22.901 & 40.723 & 61.202 & 76.559 & 8.157 & 92.597 \\
\hline GOVscr & 49.128 & 47.010 & 55.719 & 20.632 & 31.733 & 49.202 & 64.959 & 8.255 & 87.822 \\
\hline \multicolumn{10}{|c|}{ Panel C. Control variables } \\
\hline SIZE & 22.681 & 22.597 & 22.941 & 0.736 & 22.598 & 22.598 & 22.598 & 19.549 & 25.220 \\
\hline LEV & 167.434 & 158.518 & 195.174 & 463.245 & 29.095 & 64.170 & 106.638 & 0.000 & 2,834 \\
\hline ROA & 6.967 & 9.597 & -1.216 & 13.581 & 2.229 & 4.187 & 11.254 & -90.848 & 48.775 \\
\hline Boardsize & 9.151 & 6.871 & 16.244 & 5.314 & 6 & 7 & 10 & 3 & 26 \\
\hline ESIs & 0.297 & 0.286 & 0.333 & 0.458 & 0 & 0 & 1 & 0 & 1 \\
\hline
\end{tabular}

Data source: Thomson Reuters EIKON and ASSET4 database, for years 2012-2016.

Notes: Table 4 indicates the information regarding the descriptive statistics of the research variables and some key financial data as the control variables. Also, several continuous variables (i.e., SIZE, LEV, ROA) are winsorized at the 1 st and 99 th percentiles.

Table 3 explains the information regarding the main independent, dependent, and control variables. Table 1 is divided into three panels. Panel A is the dependent variable in which we use the bid-ask spread as the proxy of asymmetric information. The information shows that the mean of Spread for the pooled sample is 0.008 , while the means of the subsets sample for the Indonesian and Portuguese groups are 0.006 and 0.016 respectively. Panel B indicates the main independent variables information. As previously highlighted in the research model, the that 66.5 percent of all the sample companies have published their CSR-related information, either in a stand-alone form or as a piece of dedicated information in the annual report. In more detail, the subsample of Indonesian companies reports that 62.1 percent of the companies have dealt with non-financial reporting, while this number is higher for the Portuguese companies (80 percent on average). With regard to the information on ESG performance, each dimension of the ESG score shows that in the pooled sample, 
Gadjah Mada International Journal of Business - May-August, Vol. 22, No. 2, 2020

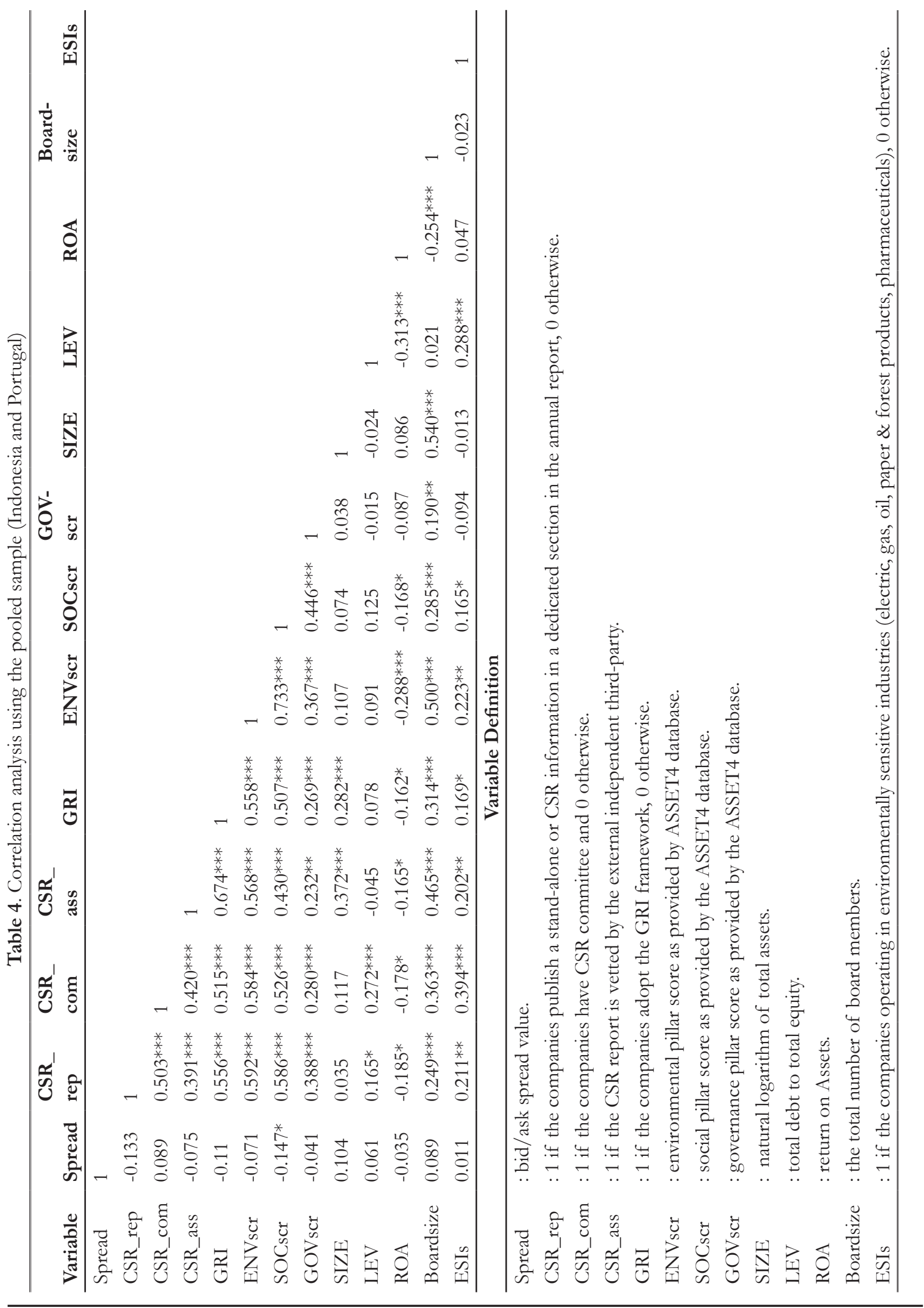


the mean score for the environmental pillar score (ENVscr) is 47.34 percent on average. In addition to this, the social pillar score (SOCscr) stands as 57.1 and the governance pillar score (GOVscr) is 49.12 percent on average. In a more specific comparison between the Indonesian and Portuguese data, it can be seen that the ESG performance scores from Portugal are higher than those of Indonesian companies. In Panel C, the information on the control variables shows that in terms of size, the Portuguese companies are relatively bigger than Indonesian companies. It can be seen through the SIZE value (natural logarithm of the total asset) of Indonesian companies which is slightly smaller (22.597) than that for Portuguese companies (22.941). However, in terms of leverage (total debt to total equity), Indonesian companies have less debt (158.518) as compared to their peers (Portugal; 195.174). Indonesian companies also indicate a positive (9.579) return on assets (ROA) while Portuguese companies are inclined to show a negative (-1.216) ROA on average. In the next section, we proceed into the correlation analysis.

The output in Table 4 presents the basic correlation between the dependent variable, the main independent variables, and the control variables. Referring to the correlation analysis output, it can be seen how CSR practices (CSR_rep, CSR_com, CSR_ass, and GRI), ESG performance scores (ENVscr, SOCscr, and GOVscr), and asymmetric information (Spread) are correlated with each other. The obtained empirical test shows that among the seven main independent variables and control variables, only SOCscr indicates a negative and significant $(p<0.1)$ correlation with the dependent variable (Spread). However, it is worth reporting that this output is obtained by employing the pooled sample with 185 observations. To be con- vinced that the obtained correlation analysis is robust for different simulations, we also performed an additional correlation analysis by distinguishing the subset of each sample according to its country groups (the information about this test was un-tabulated due to the limited space). The results using two different sub-sample groups reveal that only GRI adoption, as the proxy of CSR practices, shows a negative correlation with the Indonesian Spread, while none of the samples from the Portuguese companies adopted the GRI reporting framework in our dataset. Moreover, in respect of ESG performance and its relationship with Spread, ENVscr, SOCscr, and GOVscr displayed a negative association with the Indonesian Spread. The negative coefficient signs can also be seen in the correlation between SOCscr, GOVscr and the Portuguese Spread.

\section{Hypotheses Testing}

In this subsection, we proceed with the hypotheses testing by providing the findings of the panel data analysis's results. As previously explained in the research method section, we used three different sample groups. Given the setting of the study used data from two countries, we deliberately used the data taken from each individual country as the subset of the overall sample (Indonesia and Portugal). We also provide empirical results by employing the pooled data as the third sample group. The details of the panel data analysis in our hypotheses testing are available as follows.

Table 5 contains the empirical panel data analysis. The obtained outputs indicate that the subsample sets both from Indonesia and Portugal and the pooled sample show relatively inconsistent results. In particular, we firstly tested the association between CSR practices 
Gadjah Mada International Journal of Business - May-August, Vol. 22, No. 2, 2020

Table 5. Main panel data analysis

Spread $_{i, t}=\alpha+\beta 1 \mathrm{CSR} \cdot \mathrm{rep}_{\mathrm{i}, \mathrm{t}}+\beta 2 \mathrm{CSR} \cdot \mathrm{com}_{\mathrm{i}, \mathrm{t}}+\beta 3 \mathrm{CSR} \cdot \mathrm{ass}_{\mathrm{i}, \mathrm{t}}+\beta 4 \mathrm{GRI}_{\mathrm{i}, \mathrm{t}}+\beta 5 \mathrm{ENVscr} \mathrm{in}_{\mathrm{i}, \mathrm{t}}+\beta 6 \mathrm{SOCscr}_{\mathrm{i}, \mathrm{t}}+$ $\beta 7$ GOVscri,t $_{i, t}+\sum$ Controls $_{\mathrm{i}, \mathrm{t}} \sum$ Year $_{\mathrm{i}, \mathrm{t}}+\sum$ Industry $_{\mathrm{i}, \mathrm{t}}+\varepsilon$.

\begin{tabular}{|c|c|c|c|c|}
\hline \multirow{2}{*}{ VARIABLES } & \multirow{2}{*}{ Expected sign } & (1) & (2) & \multirow{2}{*}{$\begin{array}{r}(3) \\
\text { Pooled }\end{array}$} \\
\hline & & Indonesia & Portugal & \\
\hline \multirow[t]{2}{*}{ CSR_rep } & - & -0.0059 & 0.0979 & -0.0109 \\
\hline & & {$[-1.5943]$} & [1.4721] & {$[-1.6515]$} \\
\hline \multirow[t]{2}{*}{ CSR_com } & - & 0.0026 & 0.1120 & 0.0312 \\
\hline & & [1.1304] & [1.6816] & {$[0.8914]$} \\
\hline \multirow[t]{2}{*}{ CSR_ass } & - & 0.0021 & -0.0569 & -0.0047 \\
\hline & & {$[0.7000]$} & {$[-1.6350]$} & {$[-0.6714]$} \\
\hline \multirow[t]{2}{*}{ GRI } & - & -0.0031 & & -0.0144 \\
\hline & & {$[-1.8235]^{*}$} & & [-0.8622] \\
\hline \multirow[t]{2}{*}{ ENVscr } & - & -0.0000545 & 0.0007 & -0.0000646 \\
\hline & & {$[-0.7686]$} & {$[0.7777]$} & {$[-0.3230]$} \\
\hline \multirow[t]{2}{*}{ SOCscr } & - & -0.0000271 & -0.0051 & -0.0004 \\
\hline & & {$[-0.4874]$} & {$[-2.125]^{*}$} & {$[-1.000]$} \\
\hline \multirow[t]{2}{*}{ GOVscr } & - & -0.0000461 & -0.0000860 & -0.0000229 \\
\hline & & {$[-0.7305]$} & {$[-0.1228]$} & {$[-0.2958]$} \\
\hline \multirow[t]{2}{*}{ SIZE } & $+/-$ & 0.1470 & 0.0579 & 0.0002 \\
\hline & & {$[2.7788] * * *$} & [1.6495] & {$[0.0294]$} \\
\hline \multirow[t]{2}{*}{ LEV } & $+/-$ & 0.00000560 & 0.00000136 & 0.00000258 \\
\hline & & {$[6.3063]^{* * *}$} & {$[0.0334]$} & {$[0.5108]$} \\
\hline \multirow[t]{2}{*}{ ROA } & $+/-$ & 0.0002 & 0.0002 & 0.0002 \\
\hline & & {$[2.3501]^{*}$} & {$[0.500]$} & {$[1.000]$} \\
\hline \multirow[t]{2}{*}{ Boardsize } & $+/-$ & 0.0013 & -0.0200 & 0.0003 \\
\hline & & [1.0833] & {$[-1.5384]$} & {$[0.250]$} \\
\hline \multirow[t]{2}{*}{ ESIs } & $+/-$ & 0.0026 & -0.2410 & -0.0423 \\
\hline & & [0.400] & {$[-1.6506]$} & {$[-0.755]$} \\
\hline Year FE & & Yes & Yes & Yes \\
\hline Industry FE & & Yes & Yes & Yes \\
\hline Se Cluster & & Yes & Yes & Yes \\
\hline \multirow[t]{2}{*}{ Constant } & & $-3.326 * * *$ & -0.864 & 0.0405 \\
\hline & & {$[-2.7786]$} & [-1.0884] & {$[0.2736]$} \\
\hline Observations & & 140 & 45 & 185 \\
\hline R-squared & & 0.295 & 0.692 & 0.212 \\
\hline \multicolumn{5}{|c|}{$\begin{array}{l}\text { Notes: } t \text { statistics are available in the brackets. Each asterisk indicates statistical significance where; }{ }^{* * *} \mathrm{p}<0.01 \text {, } \\
* * \mathrm{p}<0.05 \text {, and }{ }^{*} \mathrm{p}<0.1 \text { respectively using a two-tail test. This Table reports the results of panel data analysis } \\
\text { estimation using equation } 1 \text {. The dependent variable is the asymmetric information (Spread) and the Inde- } \\
\text { pendent variablesare CSR practice (i.e., CSR_rep, CSR_com, CSR_ass, and GRI) and ESG performance (i.e., } \\
\text { ENVscr, SOCscr, and GOVscr). In the empirical test, we deliberately carried out the panel data regression } \\
\text { using three sample groups. All the specifications in the model are estimated using OLS regression by including } \\
\text { the year fixed-effect, industry fixed-effect and robust standard errors that have been clustered at the year and } \\
\text { company levels. }\end{array}$} \\
\hline
\end{tabular}


and asymmetric information. In this regard, we tested the first four hypotheses to identify the association of CSR report (CSR_rep), CSR committee (CSR_com), CSR assurance (CSR_ass) and GRI framework (GRI) with Spread. In Hypothesis 1a, we hypothesized that CSR report is negatively associated with asymmetric information (spread). The empirical evidence of Hypothesis 1a shows that the coefficient value of CSR report (CSR rep) is negative but insignificantly associated with asymmetric information (Spread). The obtained result indicates a consistent output where the test of Hypothesis 1a using Indonesia $(\beta=-0.0059)$, Portugal $(\beta=0.0979)$, and the pooled sample $(\beta=-0.0109)$ groups show no statistical association $(p>0.1)$ between CSR report and asymmetric information (Spread). Given this result, we report that Hypothesis $1 \mathrm{a}$ is unsupported. We further continued by testing Hypothesis $1 \mathrm{~b}$. In Hypothesis 1b, we argued that CSR committee (CSR_com) is negatively associated with asymmetric information (Spread). The results show that neither the Indonesian $(\beta=$ $0.0026)$ ), Portuguese $(\beta=0.1120)$ nor the pooled samples $(\beta=0.0312)$ indicated any significant association $(\mathrm{p}>0.1)$ with asymmetric information (Spread). Therefore, we report that Hypothesis $1 \mathrm{~b}$ is also statistically unsupported. The tesing further proceeded to Hypothesis 1c. In Hypothesis 1c we assumed that CSR assurance (CSR_ass) is negatively associated with asymmetric information (Spread). The empirical result noted that none of the subsample sets (Indonesian $(\beta=$ $0.0021)$ and Portuguese $(\beta=-0.0569) \mathrm{com}-$ panies) and the whole sample (pooled; $\beta=$ $-0.0047)$ showed a significant association ( $p$ $>0.1$ ) with asymmetric information (Spread). In this case, we report that Hypothesis $1 \mathrm{c}$ is unsupported. The last test on the association between CSR practice and asymmetric infor- mation was conducted by testing Hypothesis $1 \mathrm{~d}$. In this test, we expected that the adoption of GRI framework would be negatively associated with asymmetric information (Spread). The test using the pooled sample $(\beta=-0.0144)$ did not indicate any association ( $p>0.1$ ) while the Portuguese sample had no observations of GRI adoption. However, the test using the Indonesian sample group showed that there is a negative $(\beta=-0.0031)$ and significant association at a ten percent level $(p<0.1)$ of alpha on the relationship between GRI and Spread. Thus, we document that this result provides weak support for Hypothesis 1d.

Moreover, we tested the association between ESG performance and asymmetric information (Spread). This test is shown by the output test of hypotheses $2 \mathrm{a}, 2 \mathrm{~b}$, and $2 \mathrm{c}$. Regarding the direct test using the environmental score (ENVscr) as the main independent variable of Hypothesis 2a, it can be seen that none of the tests using three sample groups (Indonesian $\beta=-0.0000545$; Portuguese $\beta=$ 0.0007 ; and pooled $\beta=-0.0000646)$ showed any significant association $(p>0.1)$ between ENVscr and Spread. This means that $\mathrm{Hy}-$ pothesis $2 \mathrm{a}$ is statistically unsupported. In Hypothesis 2b, we argued that social performance, which is represented by the social pillar score (SOCscr), is associated with asymmetric information. The test showed that only the test with the Portuguese subsample set indicated a negative $(\beta=-0.0051)$ and a significant association at a ten percent level $(\mathrm{p}<$ $0.1)$. While in the Indonesian $(\beta=-0.0000271)$ and pooled samples $(\beta=-0.0004)$, the obtained coefficient values of SOCscr showed negative signs but did not indicate any significant association ( $p>0.1)$. Given the obtained significance level which stands at ten percent, we report that Hypothesis $2 \mathrm{~b}$ is weakly supported. The last hypothesis testing goes to 
Hypothesis 2c, which tested the association between governance performance (GOVscr) and asymmetric information (Spread). Similar to the previous result from the ESG test, the governance score showed negative coefficient values (Indonesia $\beta=-0.0000461$; Portugal $\beta=-0.0000860$; and pooled sample $\beta=-0.0000229)$ but all were statistically insignificant $(\mathrm{p}>0.1)$.

\section{Discussion}

Our study investigates the associations between CSR practices, ESG performance, and asymmetric information. Recalling the results of our main analysis, we document that most of the proposed hypotheses are statistically unsupported. We conjecture that CSR practices, as proxied by CSR_rep, CSR_com, CSR_ass, and GRI, are associated with asymmetric information, as surrogated by the bid-ask spread (Spread). However, the obtained outputs using the data from two different countries do not completely meet and support our ideas. The supported hypothesis (H1d) indicates that there is a weak relationships between CSR practices and asymmetric information, since only a proxy of our main independent variable (i.e., GRI) showed a weak relationship with the main dependent variable (Spread). In more detail, our findings provide the result that the presence of a CSR report (CSR_rep) does not necessarily seem value relevant in truncating the level of asymmetric information. Irrespective of the CSR-related information being provided either in a stand-alone report or combined in the annual report, the evidence from Portugal and Indonesia documents an inconclusive result, as compared with our a priori notion and the previous study of Fuhrmann et al., (2017) and Usman and Yennita, (2018). Given this circumstance, we claim that our result is slightly similar to the findings of Michelon, Pilonato, and Ricceri, (2015). They tested the relationship between CSR practices and CSR disclosure quality. In their study, CSR reports appeared as one of the proxies of CSR practices. They noted that CSR reporting, whether it is provided in the form of a stand-alone report or integrated into the annual report, does not associate with the quality of the CSR disclosure. This means that the disclosed non-financial information is mostly described as a symbolic action, which is taken by the companies just to show the public that they have been dealing with CSR-related activities. In our case, we find that there is no association between CSR reporting and asymmetric information (Spread), which confirms that the presence of CSR reports, to some extent, do not seem value relevant to diminish the level of asymmetric information, as depicted by the changes in the bid-ask spread. The potential explanation of this peculiar output could be linked with the finding of Michelon et al., (2015). Even though their study was conducted using UK companies, one of the countries with a very strict and advanced method of non-financial information reporting, yet the reported and the published information is considered to be less substantive and contains deficiencies. Among them, they pointed out the issue of a lack of completeness due to the voluntary nature of CSR reporting, which does not require a particular standard of information disclosure. They also stressed that the point of creating a CSR report, and disclosing it to the public, is mainly driven by the managers' opportunistic behavior, in which the main motive could be due to the effort to manage the stakeholders' perceptions and to gain public legitimacy. Even so, another prior study undertaken by Usman and Yennita, (2018) showed that environmental and social scores are negative- 
ly associated with asymmetric information. They carried out the study using Indonesian companies as the sample for their study. We presume that the inconclusive results we have may be driven by the different data forms, as used by Usman andYennita's (2018) study, in which they focused more on using the quarterly data while we used the yearly data.

With respect to the consequences of increasing information disclosures and the concerns about different types of data, Leuz and Verrecchia, (2000) and Botosan and Harris (2000), in their studies, highlighted that the motivation for a change in disclosure frequency is linear with its economic consequences. Botosan and Harris (2000) documented that the change in disclosure frequency can enhance both the content and the timeliness of the information disclosed to the public. They argued that if the management considers a particular segment of information to be important for an investment-related decision, the timeliness of the reporting is more likely to be enhanced through the quarterly reporting format than the yearly form. This is due to the usefulness of information that is provided in a timely manner to investors, and made available to the public, so as to allow the investors to create instantaneous buying, selling, or holding decisions for particular stocks. This argument is also relevant to the findings of Usman and Yennita, (2018) who used quarterly data from Indonesian companies. They tested the relationship between CSR practices and asymmetric information, and they found that CSR practices are negatively and significantly associated with asymmetric information (i.e., proxied by a quarterly bid-ask spread and stock price volatility). Even though using quarterly data provides different results, compared with the yearly data in our study, we argue that this phenomenon might happen due to the yearly reporting pattern that does not reveal the seasonal trends and time-varying factors which are less observable in the annual data. Therefore, Botosan and Harris, (2000), Usman and Yennita, (2018) and Usman, (2020a) suggested increasing the voluntary disclosure information to a quarterly time-based frequency, rather than using the annual-based information reporting.

Recalling the variation of asymmetric information, our results report that, from the perspective of investors, there could be a considerable number of factors that may drive investors'decisions in their investment activities. In this regard, investors need more information to reduce the level of asymmetric information among the market participants. With this, the effort to diminish the level of asymmetric information can be done by collecting relevant information (financial and/or non-financial information) about the targeted companies' stocks. Meanwhile, from the perspective of the companies, as the information holders and providers, they should be able to publicly and promptly convey the information to the public (market participants). The market's ability to absorb this information is mainly depicted through the bid-ask price changes. As noted by Nurazi et al., (2016), the transaction of stock trading activities in Indonesia adopts the order-driven market system and continuous auction system. The alteration of price changes (up and down) indicates the role of brokers, where the buyers and sellers are unable to complete the transaction by themselves in the type of order-driven market. Thus, the market participants (sellers and buyers) need the assistance of a broker to perform their actions.

Regarding the obtained evidence using the Portuguese setting, we also find that none of the proxies of CSR practices have shown a 
significant association with asymmetric information. However, one of the proxies of ESG performance (SOCscr) displays a negative and significant association with asymmetric information (Spread). Similar to the results from the Indonesian setting, CSR practices are not associated with asymmetric information in the sample group from Portugal. On the Lisbon Stock Exchange (now Euronext Lisbon, which is part of the NYSE Euronext Group), the opportunity to have more transactions on the Euronext equity trading market is greater than the transactions conducted on the Indonesian Stock Exchange. This is due to the involvement of the Lisbon Stock Exchange with the NYSE Euronext group, which allows publicly listed companies on Euronext Lisbon to access global and diversified investors worldwide. Therefore, the disclosure of voluntary non-financial information to the public is expected to be value relevant, where the presence of CSR-related information may help buyers, sellers, and brokers to lower the cost of searching for information on the best price. Thus, brokers may offer a more attractive price by offering a narrow bid-ask spread and lower fees (Foucault, Pagano, and Roell, 2013).

\section{Robustness Test}

A robustness test was conducted as an additional analysis to see whether the obtained main empirical output indicates robust results. In the robustness test, we used the lagged independent variables to see if CSR practices and ESG performance are associated with asymmetric information. The purpose of using the time-lag variable is to precisely obtain the most efficient estimation output. As pointed out by Imbens and Wooldridge, (2009) we believed that a lagged variable occurred in the past $\left(\mathrm{t}_{-1}\right)$ which could not be correlated with the error term $(\varepsilon)$ in the current time $\left(t_{0}\right)$. The independent lagged variables are thus exogenous and are deemed to be relevant and convenient factors for explaining the variation of the contemporaneous $\left(\mathrm{t}_{0}\right)$ dependent variable. In this respect, we consider that the contemporaneous variable of asymmetric information $\left(t_{0}\right)$ is supposedly influenced by the previous information of time-variant variables in the proposed empirical model. The output of the robustness test using one-year time-lagged variables is available as follows.

As seen in Table 6, we tested the robustness of our main results by presenting the robustness check's output. We used one-year time lag variables and regressed them on the variation of the contemporaneous variable of Spread. As our notion in the a priori hypotheses, we conjectured that CSR practices and ESG performance are negatively associated with asymmetric information (Spread). The obtained outputs indicated that either CSR practices or ESG performance showed a negative association with asymmetric information (Spread), even though the obtained robustness test results were slightly better (i.e., in terms of the coefficient signs consistency and the number of significant variables) than the output in the main analysis. In a more detailed analysis, CSR_rep ${ }_{\mathrm{i}, \mathrm{t}-1}$ and CSR_ass ${ }_{\mathrm{i}, \mathrm{t}-1}$ are reported to be negatively and statistically $(\mathrm{p}<$ $0.05)$ associated with asymmetric information (Spread). Regarding the other proxies of CSR practices, it can be seen that the coefficient sign of CSR_com ${ }_{\mathrm{i}, \mathrm{t}-1}$ indicates a negative sign, while $\mathrm{GRI}_{\mathrm{i},-1}$ shows positive coefficient beta but it is statistically insignificant $(p<0.05)$. Additionally, the direct test of the ESG performance variables $\left(\mathrm{ENVscr}_{\mathrm{i}, \mathrm{t}-1}, \mathrm{SOCscr}_{\mathrm{i}, \mathrm{t}-1}\right.$, and $\mathrm{GOVscr}_{\mathrm{i}, \mathrm{t}-\mathrm{1}}$ ) shows a negative association with asymmetric information and statistical insignificance $(\mathrm{p}>0.1)$. 
Table 6. Additional panel data analysis (robustness check)

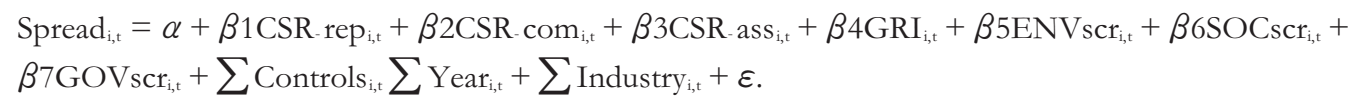

\begin{tabular}{lrr}
\hline VARIABLES & Expected sign & $(\mathbf{1})$ Spread \\
\hline CSR_repi,t-1 & - & $-\mathbf{0 . 0 1 6 5}$ \\
& & {$[-2.1153]^{* *}$} \\
CSR_com i,t-1 & - & -0.0048 \\
& & {$[-0.6666]$} \\
CSR_ass i,t-1 & - & $\mathbf{- 0 . 0 2 0 3}$ \\
& & {$[-2.4756]^{* *}$} \\
GRI i,t-1 & - & 0.0114 \\
& & {$[1.5833]$} \\
ENVscr i,t-1 & - & -0.0005 \\
& & {$[-2.000]$} \\
SOCscr I,t-1 & - & -0.0000548 \\
& & {$[-0.274]$} \\
GOVscr i,t-1 & - & -0.0003 \\
& & {$[-1.000]$} \\
SIZE i,t-1 & $+/-$ & -0.0047 \\
& & {$[-0.6025]$} \\
LEV i,t-1 & $+/-$ & 0.00000209 \\
ROA i,t-1 & & {$[0.6040]$} \\
& $+/-$ & 0.0003 \\
Boardsize i,t-1 & $+/-$ & {$[1.000]$} \\
Year FE & & $\mathbf{0 . 0 0 3 2}$ \\
Industry FE & & {$[1.8823]^{*}$} \\
Se Cluster & & Yes \\
Constant & & Yes \\
Observations & & 0.104 \\
R-squared & & $148011]$ \\
\hline & & 0.235 \\
\hline
\end{tabular}

Notes: $\mathrm{t}$ statistics are available in the brackets. Each asterisk indicates statistical significance where; $* * * \mathrm{p}<0.01,{ }^{*} \mathrm{p}<0.05$, and ${ }^{*} \mathrm{p}<0.1$ respectively using a two-tail test. This Table reports the results of panel data analysis estimation using equation 1. The dependent variable is the asymmetric information (Spread) at the contemporaneous time, and the Independent variable is CSR practice (i.e., CSR_rep, CSR_com, CSR_ass, and GRI) and ESG performance (i.e., ENVscr, SOCscr, and GOVscr) at the one-year time lag. In the robustness test, we deliberately carried out the panel data regression using the pooled sample data. All the specifications in the model are estimated using OLS regression by including the year fixed-effect, industry fixed-effect and robust standard errors that have been clustered at the year and company levels. 
The robustness test output provided a slightly different result compared with the main hypothesis testing. We argue that the use of previous time-variant variables of CSR practices indicates a more robust effect in the change of asymmetric information $\left(\operatorname{Spread}_{\mathrm{i}, \mathrm{t}-1}\right)$, in which the bid-ask spread is more likely to be reduced when the information, with respect to the CSR-related information and ESG performance, is fully absorbed by the market participants. This denotes that in order to be appropriately absorbed by the market, a non-financial information disclosure needs some time lag. Thus, as pointed out by Botosan and Harris, (2000) and Usman and Yennita, (2018) companies should be able to immediately disseminate their CSR-related activities to the public after they have done them. A regular publication on environmental, social, and governance-related activities could also be endorsed through their corporate social media platforms (e.g., Facebook, Twitter, Instagram, Youtube, Linkedin, and so forth). At the end of the year, the CSR team may gather all the CSR and ESG related actions during the year in a compilation report (e.g., in the stand-alone report or as a dedicated page in the annual report). With this action, the stakeholders may have better understanding about companies' CSR engagements, and use this type of publicly available information to lower the potential asymmetric information among the market's participants.

\section{Conclusion}

This study examines the association between CSR practices, ESG performance, and asymmetric information. Using a sample from two countries with 185-panel data observations in total, we find that neither CSR practices nor ESG performance are strongly associated with asymmetric information. In this regard, the hypotheses testing indicates that only GRI, as one of the proxies of CSR practices, is significantly associated with asymmetric information (Spread). Meanwhile, out of three surrogate indicators of ESG performance, only SOCscr is statistically associated with asymmetric information (Spread). Based on the obtained empirical evidence, we infer that the information about CSR reporting practices and ESG performance scores needs some time lag to be fully absorbed by the market's participants and to be reflected in the bid-ask price changes. Even though the main test was performed using contemporaneous data $\left(\mathrm{t}_{0}\right)$, the results show that there is a weak relationship between CSR practices, ESG performance, and asymmetric information. We also confirm the importance of a time lag through the additional analysis, in which the association between each lagged independent variable of interest $\left(t_{-1}\right)$ (CSR practices and ESG performance) shows a stronger relationship with the contemporaneous $\left(\mathrm{t}_{0}\right)$ asymmetric information.

Finally, our study contributes to the literature in three ways. First, by providing a comparative study using the data from two different settings for the study and institutional backgrounds. Second, the comparison study might facilitate us to further identify and investigate the potential relationship that could occur between the concept of CSR practices, ESG performance, and asymmetric information in each country. Thus, by analyzing this relation grounded on legitimacy and the signaling theory, it may enable us to develop more testable hypotheses with respect to such a relation. Third, our systematic literature review indicates that there is no prior study focused on combining the concept of CSR practices, ESG performance, and asymmetric information in the same research 
model. Hence, our findings could enhance the existing literature by providing empirical evidence on the nexus between CSR practices, ESG performance, and asymmetric information studies.

\section{Limitation}

The more obvious limitation of our study relates to the inability to control for the self-selection sample bias. Given that, in the sample selection procedure, we only focused on using the companies that had, at least once, published their non-financial information (CSR, sustainability report, environmental report, etc) for the public. On top of that, we only collected data from those companies covered by Thomson Reuters EIKON and
Thomson Reuters ASSET4 databases. Thus, we lost many observations since not all the companies that have published their non-financial information are indexed in Thomson Reuters databases. Given this situation, our estimation could have incurred a potential endogeneity problem, which is problematic in accounting and finance research (Lennox et al., 2012; Tucker, 2010). In addition to this, we acknowledge that we do not clearly indicate and investigate the causal-effect mechanism by initiating an observational study. Thus, future research may decide to adopt propensity score matching (PSM) to deal with the causal-effect mechanism regarding the number of companies that can be classified as CSR adopters and non-adopters.

\section{References}

Amran, A., Lee, S. P., and Devi, S. S. (2014). The influence of governance structure and strategic corporate social responsibility toward sustainability reporting quality. Business Strategy and the Environment, 23(4), 217-235. https://doi.org/10.1002/bse.1767

Bagnoli, M., and Watts, S. G. (2017). Voluntary assurance of voluntary CSR disclosure. Journal of Economics and Management Strategy, 26(1), 205-230. https://doi.org/10.1111/jems.12171

Baltagi, B. H. (2008). Econometric analysis of panel data. Econometric Theory, 13(05), 351. https:// doi.org/10.1017/S0266466600006150

Bebbington, J., Larrinaga, C., and Moneva, J. M. (2008). Corporate social reporting and reputation risk management. Accounting, Auditing and Accountability Journal, 21(3), 337-361. https://doi.org/10.1108/09513570810863932

Benlemlih, M., Shaukat, A., Qiu, Y., and Trojanowski, G. (2016). Environmental and social disclosures and firm risk. Journal of Business Ethics, 152(3), 613-626. https://doi.org/10.1007/ s10551-016-3285-5

Birkey, R. N., Michelon, G., Patten, D. M., and Sankara, J. (2016). Does assurance on CSR reporting enhance environmental reputation? an examination in the U.S. context. Accounting Forum, 40(3), 143-152. https://doi.org/10.1016/j.accfor.2016.07.001

Botosan, C. A., and Harris, M. S. (2000). Motivations for a change in disclosure frequency and its consequences: An examination of voluntary quarterly segment disclosures. Journal of Accounting Research, 38(2), 329. https://doi.org/10.2307/2672936

Briem, C. R., and Wald, A. (2018). Implementing third-party assurance in integrated reporting: Companies' motivation and auditors' role. Accounting, Auditing and Accountability Journal, 31(5), 1461-1485. https://doi.org/10.1108/AAAJ-03-2016-2447 
Gadjah Mada International Journal of Business - May-August, Vol. 22, No. 2, 2020

Brooks, C., and Oikonomou, I. (2018). The effects of environmental, social and governance disclosures and performance on firm value: A review of the literature in accounting and finance. British Accounting Review, 50(1), 1-15. https://doi.org/10.1016/j.bar.2017.11.005

Brown, H. S., de Jong, M., and Levy, D. L. (2009). Building institutions based on information disclosure: Lessons from GRI's sustainability reporting. Journal of Cleaner Production, 17(6), 571-580. https://doi.org/10.1016/j.jclepro.2008.12.009

Cho, C. H., Michelon, G., Patten, D. M., and Roberts, R. W. (2014). CSR report assurance in the USA: An empirical investigation of determinants and effects. Sustainability Accounting, Management and Policy Journal, 5(2), 130-148. https:/ / doi.org/10.1108/SAMPJ-01-2014-0003

Cho, S. Y., Lee, C., and Pfeiffer, R. J. (2013). Corporate social responsibility performance and information asymmetry. Journal of Accounting and Public Policy, 32(1), 71-83. https://doi. org/10.1016/j.jaccpubpol.2012.10.005

Connelly, B. L., Certo, S. T., Ireland, R. D., and Reutzel, C. R. (2011). Signaling theory: A review and assessment. Journal of Management, 37(1), 39-67. https://doi. org/10.1177/0149206310388419

Cormier, D., and Magnan, M. (2015). The economic relevance of environmental disclosure and its impact on corporate legitimacy: An empirical investigation. Business Strategy and the Environment, 24(6), 431-450. https://doi.org/10.1002/bse.1829

Deegan, C., Cooper, B. J., and Shelly, M. (2006). An investigation of TBL report assurance statements: Australian evidence. Australian Accounting Review, 16(2), 2-18. https://doi.org/ https://doi.org/10.1111/j.1835-2561.2006.tb00355.x

Dhaliwal, D. S., Radhakrishnan, S., Tsang, A., and Yang, Y. G. (2012). Nonfinancial disclosure and analyst forecast accuracy: International evidence on corporate social responsibility disclosure. The Accounting Review, 87(3), 723-759. https://doi.org/10.2308/accr-10218

Ding, R., and Hou, W. (2015). Retail investor attention and stock liquidity. Journal of International Financial Markets, Institutions and Money, 37, 12-26. https://doi.org/10.1016/j.intfin.2015.04.001

$\mathrm{E}$ and Y. (2017). Is your nonfinancial performance revealing the true value of your business to investors? In Ernst and Young.

European Commission. (2014). Directive 2014/95/EU of the European Parliament and of the Council of 22 October 2014. Official Journal of the European Union. https://doi.org/ http://eur-lex.europa.eu/pri/en/oj/dat/2003/1_285/1_28520031101en00330037.pdf

Famiola, M., and Adiwoso, S. A. (2016). Corporate social responsibility diffusion by multinational subsidiaries in Indonesia: organisational dynamic and institutional effect. Social Responsibility Journal, 12(1), 117-129. https://doi.org/10.1108/SRJ-10-2013-0128

Foucault, T., Pagano, M., and Roell, A. (2013). Market Liquidity: Theory, Evidence, and Policy. In O. USA (Ed.), Disputatio. https://doi.org/10.1093/acprof

Fuhrmann, S., Ott, C., Looks, E., and Guenther, T. W. (2017). The contents of assurance statements for sustainability reports and information asymmetry. Accounting and Business Research, 47(4), 369-400. https://doi.org/10.1080/00014788.2016.1263550

GRI. (2014). G4 Sustainability Reporting Guidelines - Reporting Principles and Standard Disclosures. Global Reporting Initiative, 1-97. https://doi.org/https://www.globalreporting. org/resourcelibrary/G3-Guidelines-Incl-Technical-Protocol.pdf 
Hąbek, P., and Wolniak, R. (2016). Assessing the quality of corporate social responsibility reports: the case of reporting practices in selected European Union member states. Quality and Quantity, 50, 399-420. https://doi.org/10.1007/s11135-014-0155-z

Hahn, R., and Lulfs, R. (2014). Legitimizing negative aspects in GRI-oriented sustainability reporting: A qualitative analysis of corporate disclosure strategies. Journal of Business Ethics, 123(3), 401-420. https://doi.org/10.1007/s10551-013-1801-4

Hendarto, K. A. (2009). The Implementation of Corporate Social Responsibility (CSR) in Central Java Earthquake: A Preliminary Study on Consumer Belief, Attitude, and Purchase Intention. Gadjah Mada International Journal of Business, 11(3), 409. https://doi.org/10.22146/ gamaijb.5522

Hodge, K., Subramaniam, N., and Stewart, J. (2009). Assurance of sustainability reports: Impact on report users' confidence and perceptions of information credibility. Australian Accounting Review, 19(3), 178-194. https://doi.org/10.1111/j.1835-2561.2009.00056.x

Imbens, G. W., and Wooldridge, J. M. (2009). Recent developments in the econometrics of program evaluation. Journal of Economic Literature, 47(1), 5-86. https://doi.org/10.1257/ jel.47.1.5

Junior, R. M., and Best, P. (2017). GRI G4 content index: Does it improve credibility and change the expectation - performance gap of GRI-assured sustainability reports? Sustainability Accounting, Management and Policy Journal, 8(5), 571-594. https://doi.org/10.1108/ SAMPJ-12-2015-0115

Khan, M., Serafeim, G., and Yoon, A. (2016). Corporate sustainability: First evidence on materiality. The Accounting Review, 91(6), 1697-1724. https://doi.org/https://doi.org/10.2308/ accr-51383

KPMG. (2017). The KPMG survey of corporate responsibility reporting 2017. In KPMG. https://doi.org/10.1038/nnano.2013.238

KPMG International. (2015). KPMG survey of corporate responsibility reporting 2015. In KPMG Corporate Responsibility Reporting. https://doi.org/www.kpmg.com/sustainability

La Porta, R., Lopez-de-Silanes, F., Shleifer, A., and Vishny, R. (2000). Investor protection and corporate governance. Journal of Financial Economics, 58(1-2), 3-27. https://doi.org/10.1016/ S0304-405X(00)00065-9

Lang, M. H., and Lundholm, R. J. (2000). Voluntary disclosure and equity offerings: reducing information asymmetry or hyping the stock? Contemporary Accounting Research, 17(4), 623662. https://doi.org/10.1506/9N45-F0JX-AXVW-LBWJ

Lennox, C. S., Francis, J. R., and Wang, Z. (2012). Selection models in accounting research. The Accounting Review, 87(2), 589-616. https://doi.org/10.2308/accr-10195

Leuz, C., and Verrecchia, R. E. (2000). The economic consequences of increased disclosure. Journal of Accounting Research, 38(1), 91-124. https://doi.org/10.2469/dig.v32.n1.1001

Lys, T., Naughton, J. P., and Wang, C. (2015). Signaling through corporate accountability reporting. Journal of Accounting and Economics, 60(1), 56-72. https://doi.org/10.1016/j.jacceco.2015.03.001

Mahoney, L. S., Thorne, L., Cecil, L., and LaGore, W. (2013). A research note on standalone corporate social responsibility reports: Signaling or greenwashing? Critical Perspectives on Accounting, 24(4-5), 350-359. https://doi.org/10.1016/j.cpa.2012.09.008 
Gadjah Mada International Journal of Business - May-August, Vol. 22, No. 2, 2020

Manurung, A. M., and Basuki, H. (2010). An analytical assessment of assurance practices in social environmental and sustainable reporting in the United Kingdom and North America. Gadjah Mada International Journal of Business, 12(1), 75-115.

Mercer, M. (2004). How do investors assess the credibility of management disclosures? Accounting Horizons, 18(3), 185-196. https://doi.org/10.2308/acch.2004.18.3.185

Michelon, G., and Parbonetti, A. (2012). The effect of corporate governance on sustainability disclosure. Journal of Management and Governance, 16(3), 477-509. https://doi.org/10.1007/ s10997-010-9160-3

Michelon, G., Pilonato, S., and Ricceri, F. (2015). CSR reporting practices and the quality of disclosure: An empirical analysis. Critical Perspectives on Accounting, 33, 59-78. https://doi. org/10.1016/j.cpa.2014.10.003

Michelon, G., Pilonato, S., Ricceri, F., and Roberts, R. W. (2016). Behind camouflaging: Traditional and innovative theoretical perspectives in social and environmental accounting research. Sustainability Accounting, Management and Policy Journal, 7(1), 2-25. https://doi. org/10.1108/09574090910954864

Moneva, M., Archel, P., and Correa, C. (2006). GRI and the camouflaging of corporate unsustainability. Accounting Forum, 30(1), 121-137. https://doi.org/10.1016/j.accfor.2006.02.001

Moroney, R., Windsor, C., and Aw, Y. T. (2011). Evidence of assurance enhancing the quality of voluntary environmental disclosures: An empirical analysis. Accounting and Finance, 52(March 2011), 903-939. https:// doi.org/10.1111/j.1467-629X.2011.00413.x

Muller, A., and Kolk, A. (2009). CSR Performance in emerging markets evidence from mexico. Journal of Business Ethics, 85(SUPPL. 2), 325-337. https://doi.org/10.1007/s10551-0089735-y

Neu, D., Warsame, H., and Pedwell, K. (1998). Managing public impressions: environmental disclosures in annual reports. Accounting, Organizations and Society, 23(3), 265-282. https:// doi.org/10.1016/S0361-3682(97)00008-1

Nurazi, R., Santi, F., and Usman, B. (2015). Tunnelling: evidence from Indonesia stock exchange. Asian Academy of Management Journal of Accounting and Finance, 11(2), 127-150.

Nurazi, R., and Usman, B. (2019). Does search engine query data contribute to returns and liquidity? Serbian Journal of Management, 14(1), 1-26. https://doi.org/10.5937/sjm14-14992

Nurazi, R., Usman, B., and Kananlua, P. S. (2016). Does bid/ask spread react to the increase of internet search traffic? International Research Journal of Business Studies, 8(3), 181-196.

Patten, D. M., and Zhao, N. (2014). Standalone CSR reporting by U.S. retail companies. Accounting Forum, 38(2), 132-144. https:/ / doi.org/10.1016/j.accfor.2014.01.002

Pedhazur, E. J. (1997). Multiple regression in behavioral research. Retrieved from https://www.amazon.com/J-Pedhazur-Multiple-Regression-Behavioral/dp/B008VR4WMG

Pérez, A. (2015). Corporate reputation and CSR reporting to stakeholders. Corporate Communications: An International Journal, 20(1), 11-29. https:/ / doi.org/10.1108/CCIJ-01-2014-0003

Peters, G. F., and Romi, A. M. (2015). The association between sustainability governance characteristics and the assurance of corporate sustainability reports. Auditing: A Journal of Practice and Theory, 34(1), 163-198. https://doi.org/10.2308/ajpt-50849

Pope, S., and Wæraas, A. (2016). CSR-washing is rare: A conceptual framework, literature review, and critique. Journal of Business Ethics, 137(1), 173-193. https://doi.org/10.1007/s10551- 
015-2546-z

Romero, S., Fernandez-Feijoo, B., and Ruiz, S. (2014). Perceptions of quality of assurance statements for sustainability reports. Social Responsibility Journal, 10(3), 480-499. https://doi. org/10.1108/SRJ-10-2012-0130

Rutherford, B. A. (2003). Obfuscation, textual complexity and the role of regulated narrative accounting disclosure in corporate governance. Journal of Management and Governance, 7(2), 187-210. https://doi.org/10.1023/A:1023647615279

Simnett, R., Vanstraelen, A., and Chua, W. F. (2009). Assurance on sustainability reports: An international comparison. The Accounting Review, 84(3), 937-967. https://doi.org/10.2308/ accr.2009.84.3.937

Steinmeier, M., and Stich, M. (2017). Does sustainability assurance improve managerial investment decisions? European Accounting Review, (December), 1-33. https://doi.org/10.1080 /09638180.2017.1412337

Stiglitz, J. E. (2002). Information and the change in the paradigm in economics information. The American Economic Review, 92(3), 460-501. https:/ / doi.org/10.1257/00028280260136363

Suchman, M. C. (1995). Managing legitimacy: Strategic and institutional approaches. Academy of Management Review, 20(3), 571-610. https://doi.org/10.5465/AMR.1995.9508080331

Tucker, J. W. (2010). Selection bias and econometric remedies in accounting and finance research. Journal of Accounting Literature, 29(1), 31-57. https://doi.org/10.1016/j.bmc.2009.11.051

Usman, B. (2019). Ownership structures, control mechanism and related party transaction: An empirical study of the Indonesian public listed companies. International Journal of Economics and Management, 13(1), 1-20.

Usman, B. (2020a). CSR performance, firm's attributes, and sustainability reporting. International Journal of Business and Society, 21(2), 521-539.

Usman, B. (2020b). CSR reports, CSR disclosure quality, and corporate reputations: A systematic literature review. Indonesian Journal of Sustainability Accounting and Management, 4(1). https:// doi.org/10.28992/IJSAM.V4I1.166

Usman, B., and Tandelilin, E. (2014). Internet search traffic and its influence on liquidity and returns of Indonesian stocks: An empirical study. Journal of Indonesian Economy and Business, 29(3), 203-221.

Usman, B., and Yennita, Y. (2018). CSR Practice and asymmetry information of Indonesian public listed companies. International Research Journal of Business Studies, 11(1), 45-66. https:// doi.org/https://doi.org/10.21632/irjbs

Waagstein, P. R. (2011). The mandatory corporate social responsibility in Indonesia: Problems and implications. Journal of Business Ethics, 98(3), 455-466. https://doi.org/10.1007/ s10551-010-0587-x

Yoon, B., Lee, J. H., and Ryan, B. (2018). Does ESG performance enhance firm value? Evidence from Korea. Sustainability, 10,1-18. https://doi.org/10.3390/su10103635 